\title{
Immunoreactivity of B-Cell Markers (CD79a, L26) in Rare Cases of Extranodal Cytotoxic Peripheral T- (NK/T-) Cell Lymphomas
}

Karin Blakolmer, M.D., Michael Vesely, M.D., J. Alain Kummer, M.D., Wolfgang Jurecka, M.D., Christine Mannhalter, Ph.D., Andreas Chott, M.D.

Departments of Clinical Pathology (KB, AC), Laboratory Medicine (CM), and General Dermatology (WJ), General Hospital Vienna, University of Vienna, Vienna, Austria and Departments of Pathology, Free

University Hospital, Amsterdam, The Netherlands (JAK), and Hospital Lainz, Vienna, Austria (MV)

The monoclonal antibodies L26 (CD20) and CD79a are very useful reagents for the immunohistochemical assessment of B-cell lineage in lymphoproliferative disorders. Although very few CD20-positive peripheral T-cell lymphomas (PTL) have been reported, comprehensive analyses of $\mathrm{CD79a}$ reactivity in extranodal PTL and NK/T-cell lymphomas have not been performed previously. This study investigated CD79a (clone JCB117) and CD20 reactivity in 94 extranodal non-B-cell lymphomas (enteropathy-type intestinal T-cell lymphoma $[n=$ 52], nasal NK/T-cell lymphoma $[n=11]$, and primary cutaneous PTL $[n=31]$ ) and in 17 cases of nodal PTL, unspecified. In four cases (enteropathytype intestinal T-cell lymphoma $[n=3]$ and nasal NK/T-cell lymphoma $[n=1]$ ), the majority of tumor cells stained for CD79a (all CD20 negative) and one cutaneous PTL, unspecified, was $\mathrm{CD20}$ positive (CD79a negative). Extensive immunophenotyping and polymerase chain reaction-based molecular analyses revealed that all five B-cell marker-positive extranodal lymphomas had a cytotoxic phenotype and did indeed represent monoclonal peripheral T-cell proliferations. To minimize the risk of misinterpretation of lymphoma cell lineage, especially in cases of extranodal lymphoproliferative disease, we suggest the use of both CD79a and CD20 in combination with a panel of antibodies reactive to $T$ cells, such as $\beta F 1$ and CD5, and to T cells and NK cells, such as CD3, CD2, CD56, and TIA-1.

Copyright (C) 2000 by The United States and Canadian Academy of Pathology, Inc

VOL. 13, NO. 7, P. 766, 2000 Printed in the U.S.A.

Date of acceptance: January 10, 2000.

Address reprint requests to: Andreas Chott, M.D., General Hospital Vienna, Department of Clinical Pathology, Währinger Gürtel 18-20, A-1090 Vienna, Austria; e-mail: andreas.chott@akh-wien.ac.at; fax: 4314053402.
KEY WORDS: CD79a, L26, NK/T-cell lymphoma, Peripheral T-cell lymphoma.

Mod Pathol 2000;13(7):766-772

Immunohistochemistry on paraffin-embedded sections is a valuable technique in both diagnostic and investigative pathology as it optimally combines immunoreactivity and tissue morphology. Especially in hematopathology, immunohistochemistry has become an integral part of the diagnostic workup. An increasing number of antibodies that are reactive on routinely processed tissue has contributed substantially to the understanding of hematopoietic malignancies in general and to malignant lymphomas in particular. The report on the revised European-American classification of lymphoid neoplasms includes a record of the most characteristic immunophenotype for each lymphoma entity, and the majority of antigens listed can be detected on paraffin sections by commercially available antibodies $(1,2)$. Some antibodies, such as those that recognize CD20 and CD79a, have gained widespread acceptance because they are considered to be largely B-lineage restricted and therefore useful for differential diagnosis of B-cell versus T-cell lymphoma (3-9). Although occasional examples of CD20-positive T-cell lymphomas have been reported $(5,10,11)$, to our knowledge no case of CD79a-positive peripheral T-cell lymphoma (PTL) has been published. During an ongoing study on intestinal T-cell lymphomas, one of these cases showed reactivity to CD79a in a significant proportion of tumor cells. Prompted by this observation, additional cases of extranodal PTLs and NK/T-cell lymphomas were evaluated for immunoreactivity to CD79a. This report describes the histopathologic, immunophenotypic, molecular, and clinical findings of five cases, four of which were reactive to CD79a and one to CD20. 


\section{MATERIALS AND METHODS}

\section{Tissue}

To study the reactivity of CD79a and CD20 in PTLs and NK/T-cell lymphomas, a total of 111 cases were retrieved from the files of the Department of Clinical Pathology, General Hospital Vienna. According to the World Health Organization (WHO) classification of neoplastic diseases of the hematopoietic and lymphoid tissues (12), they were composed of 52 cases of enteropathy-type intestinal T-cell lymphomas, 11 cases of nasal NK/T-cell lymphomas, 31 cases of primary cutaneous PTLs (mycosis fungoides [ $n=14$ ], PTL unspecified [ $n=7]$, and CD30-positive lymphoproliferative disease [ $n=10]$ ), and 17 cases of nodal PTLs, unspecified. Histologic examination was done on formalin-fixed (7.5\%, pH 7.4), paraffin-embedded tissue. Sections were stained with hematoxylin and eosin, periodic acid-Schiff, and Giemsa for routine histopathologic evaluation. One patient (Case 3) has been included in a previously published series on intestinal T-cell lymphomas (13).

\section{Immunohistochemistry}

Immunostaining was done using the polyclonal antibodies anti-CD3 (Dako, Copenhagen, Denmark; 1:400) and TdT (Dako; 1:20) and the monoclonal antibodies CD79a (clone JCB117; Dako; 1:25), L26 (Dako; 1:200), CD34 (Immunotech, Marseille, France; 1:100), $\beta$ F1 (T-Cell Sciences, Woburn, MA; 1:10), CD1a (Novocastra, Newcastle, UK; 1:20), CD2 (Novocastra; 1:20), CD4 (Novocastra; 1:20), CD5 (Novocastra; 1:20), CD7 (Novocastra; 1:40), CD8 (Dako; 1:30), TIA-1 (Coulter, Hialeah, FL; 1:800), CD56 (Sanbio, Uden, The Netherlands; 1:200), CD57 (Becton-Dickinson, San Jose, CA; 1:10), CD30 (Dako; 1:80), EMA (Dako; 1:100), LMP1 (Dako; 1:100) and MIB-1 (Immunotech; 1:50). The monoclonal antibody Granzyme B-4 (GB-4, 1:50) was generously provided by Dr. J.A. Kummer, Department of Pathology, Free University Hospital, Amsterdam, The Netherlands. Pretreatment for unmasking of antigens was done either by digestion with $0.05 \%$ preheated protease (type XXIV; Sigma Chemical Co., St.Louis, MO) in TRIS-buffered saline for $5 \mathrm{~min}$ at $37^{\circ} \mathrm{C}$ (for $\beta \mathrm{F} 1$ and $\mathrm{CD} 3$ ), by microwaving in citrate buffer $(10 \mathrm{mmol} / \mathrm{L}, \mathrm{pH} 6.0)$ twice for 5 min each at $600 \mathrm{~W}$ (for CD79a, CD34, TdT, CD1a, CD7, GB-4, TIA-1, CD30, EMA, LMP1, and MIB-1), or by autoclaving at 1 bar for $20 \mathrm{~min}$, followed by cooling down for $40 \mathrm{~min}$ (for CD2, CD4, CD5, CD8, and CD56). Application of CD34, TdT, $\beta \mathrm{F} 1, \mathrm{CD} 3, \mathrm{CD} 4$, CD5, and CD8 was followed by incubation with biotinylated goat antirabbit IgG (for TdT and CD3) or horse antimouse IgG (for CD34, $\beta$ F1, CD4, CD5, and CD8) as the secondary antibody and then by peroxidase-conjugated streptavidin (Super Sensitive HRP Label; Biogenex, San Ramon, CA). Staining was developed using 3-amino-9-ethylcarbazole as the chromogen (Sigma) in the presence of $\mathrm{H}_{2} \mathrm{O}_{2}$. For the remaining antibodies, biotinylated horse antimouse IgG was used as the secondary antibody followed by Vectastain Elite ABC reagent (Vector Laboratories, Burlingame, CA) and 3,3'-diaminobenzidine as a chromogen (Fluka, Buchs, Switzerland) in the presence of $\mathrm{H}_{2} \mathrm{O}_{2}$. Nonspecific reactivity was assessed by omission of the primary antibodies. Staining of tumor cells was scored: + , more than $50 \%$ positive; \pm , 20 to $50 \%$ positive; - , fewer than $20 \%$ positive; $\mathrm{I}+$, individual tumor cells positive. The latter score was used for TIA-1 and GB-4 only.

\section{EBER In Situ Hybridization}

Fluorescein-labeled oligonucleotides complementary to Epstein-Barr virus small nuclear RNA (EBER) $1 / 2$ were used according to the instructions of the manufacturer (PNA ISH detection kit, Dako) under RNAse-free conditions.

\section{T- and B-cell Clonality Analyses by Polymerase Chain Reaction}

For the detection of T-cell and B-cell clonality, polymerase chain reaction (PCR) techniques were used to amplify rearranged T-cell receptor (TCR) $\gamma$-chain and immunoglobulin heavy chain genes, respectively, as described (14). Genomic DNA was extracted from formalin-fixed, paraffin-embedded tissue by proteinase $\mathrm{K}$ digestion without detergents or EDTA according to Frank et al. (15). PCR products were separated on precast $6 \%$ polyacrylamide gels (Novex, San Diego, CA).

\section{RESULTS}

Identification of Five Extranodal Peripheral T-(NK/T-) Cell Lymphomas Reactive to CD79a or CD20

A total of 111 cases of various types of extranodal PTL and NK/T-cell lymphomas and a group of nodal PTL, unspecified, were studied for the immunoreactivity of the B-cell markers CD79a and CD20 on paraffin sections (Table 1). None of the 17 nodal PTL was reactive to CD79a or CD20. In contrast, 5 of the 94 extranodal lymphomas $(5.3 \%)$ stained either for CD79a (enteropathy-type intestinal T-cell lymphoma $[n=3]$ and nasal NK/T-cell lymphoma $[n=$ 1]) or for CD20 (primary cutaneous PTL, unspecified $[n=1])$, indicating a mutually exclusive reactivity pattern of the two B-cell markers. The clinical presentation and follow-up, histopathology, immunologic phenotyping, and PCR-based clonality 
TABLE 1. Peripheral T-Cell Lymphomas and NK/T-Cell Lymphomas Evaluated for CD79a and CD20 Immunoreactivity

\begin{tabular}{lccc}
\hline \multicolumn{1}{c}{ Diagnosis $^{a}$} & $n$ & CD79a + & CD20+ \\
\hline Enteropathy-type intestinal T-cell lymphoma & 52 & 3 & - \\
Nasal NK/T-cell lymphoma & 11 & 1 & - \\
Primary cutaneous PTL & 14 & - & - \\
$\quad$ Mycosis fungoides & 7 & - & 1 \\
PTL, unspecified & 10 & - & - \\
CD30+ lymphoproliferative disease & \\
Nodal PTL, unspecified & 17 & - & - \\
Total & 111 & 4 & 1 \\
\hline
\end{tabular}

PTL, peripheral T-cell lymphomas.

${ }^{a}$ According to the World Health Organization classification (12).

${ }^{b}$ According to the EORTC classification for primary cutaneous lymphomas (27): large cell cutaneous T-cell lymphoma CD30+, anaplastic $(n=2)$; pleomorphic $(n=8)$.

analyses of these five cases are discussed in the following sections.

\section{Clinical Findings}

The clinical findings are summarized in Table 2. Two patients presented with localized cutaneous lesions (Cases 1 and 5), two patients had multiple jejunal tumors (Cases 2 and 3), and one patient had gastric and colonic lesions (Case 4). The clinical course was aggressive in all cases and characterized by progressive disease irrespective of therapeutic interventions.

\section{Histopathology}

The histopathology of each of the five lymphomas is shown in the left panel in Figure 1. The nasal and cutaneous lesions in Case 1 were histologically identical showing nonangiocentric, densely packed medium- and large-sized cells with often clear cytoplasm and moderately pleomorphic nuclei. Cases 2 and 3 had multiple jejunal tumors each composed of monomorphic small- to medium-sized cells that were of monocytoid clear cell appearance (in Case 2) or displayed lymphoplasmacytoid features with narrow, slightly basophilic cytoplasm (in Giemsastained sections) and inconspicuous nuclei (in Case 3). As both of these cases additionally showed prominent intraepithelial lymphoma cell accumulations resembling lymphoepithelial lesions, they strikingly mimicked low-grade B-cell lymphoma of mucosa-associated lymphoid tissue (MALT) type. The gastric and ileal lesions in Case 4 showed different histologies: the gastric lymphoma infiltrate exhibited mostly medium-sized and a few large pleomorphic cells, whereas the multiple intestinal tumors were mainly composed of anaplastic large cells (not shown). Two of the three intestinal T-cell lymphomas (Cases 2 and 4) were enteropathy associated. In Case 5, the band-like cutaneous infiltrate extended into the deep dermis and showed mild epidermotropic features without formation of Pautrier's microabscesses. As shown in Figure 1 (bottom row, left panel), the tumor cells were just slightly larger than reactive lymphocytes and contained pleomorphic, sometimes deeply indented nuclei.

\section{Immunologic Phenotyping and Clonality Analyses}

The antigen profiles of the four cases that were reactive to CD79a (Cases 1 through 4 ) and the CD20-positive lymphoma (Case 5) are summarized in Table 3. Some immunostains are shown in Figure 1.

Among the CD79a-positive samples of all four cases, the majority of tumor cells showed membrane and cytoplasmic staining that was only slightly weaker than in plasma cells present in ad-

TABLE 2. Clinical Findings in Five Patients with B-Cell Marker-Positive Peripheral T-Cell Lymphomas

\begin{tabular}{|c|c|c|c|c|c|}
\hline Case & Diagnosis & Age/Sex & Presentation & Follow-Up & Survival \\
\hline 1 & $\begin{array}{l}\text { Nasal NK/T-cell lymphoma, } \\
\text { CD79a+ }\end{array}$ & $77 / \mathrm{M}$ & $\begin{array}{l}\text { Ulcerated lesion on } \\
\text { tip of nose } \\
\text { extending into nasal } \\
\text { cavity }\end{array}$ & $\begin{array}{l}\text { Local radiotherapy } \\
\text { cutaneous } \\
\text { recurrences, } \\
\text { parapharyngeal } \\
\text { tumor } 10 \text { mo after } \\
\text { presentation }\end{array}$ & $\begin{array}{l}\text { Died of pharyngeal } \\
\text { hemorrhage } 11 \\
\text { mo after diagnosis }\end{array}$ \\
\hline 2 & $\begin{array}{l}\text { Enteropathy-type intestinal } \\
\text { T-cell lymphoma CD79a+ }\end{array}$ & $63 / \mathrm{M}$ & Jejunal tumor & $\begin{array}{l}6 \times \mathrm{CHOP} \text {, intestinal } \\
\text { recurrence, } \\
\text { perforation }\end{array}$ & $\begin{array}{l}\text { Died of peritonitis } \\
11 \text { mo after } \\
\text { diagnosis }\end{array}$ \\
\hline 3 & $\begin{array}{l}\text { Enteropathy-type intestinal } \\
\text { T-cell lymphoma CD79a+ }\end{array}$ & $42 / \mathrm{M}$ & $\begin{array}{l}\text { Perforated jejunal } \\
\text { tumor }\end{array}$ & No therapy & $\begin{array}{l}\text { Died of intestinal } \\
\text { hemorrhage } 1 \text { mo } \\
\text { after diagnosis }\end{array}$ \\
\hline 4 & $\begin{array}{l}\text { Enteropathy-type intestinal } \\
\text { T-cell lymphoma CD79a }+\end{array}$ & $45 / \mathrm{M}$ & $\begin{array}{l}\text { Gastric and colonic } \\
\text { ulcers }\end{array}$ & $\begin{array}{l}2 \times \text { CHOP, small } \\
\text { bowel obstruction }\end{array}$ & $\begin{array}{l}\text { Died } 3 \text { mo after } \\
\text { diagnosis }\end{array}$ \\
\hline 5 & $\begin{array}{l}\text { Peripheral T-cell lymphoma, } \\
\text { unspecified CD20+ }\end{array}$ & $38 / \mathrm{M}$ & $\begin{array}{l}\text { Localized indurated } \\
\text { plaque-like } \\
\text { cutaneous lesions at } \\
\text { jugular fossa }\end{array}$ & $\begin{array}{l}4 \times \text { CHOP, no } \\
\text { response, } \\
\text { appearance of } \\
\text { additional skin } \\
\text { lesions }\end{array}$ & Alive at $6 \mathrm{mo}$ \\
\hline
\end{tabular}

CHOP, cyclophosphamide, hydroxydaunomycin, vicristine, and prednisone. 

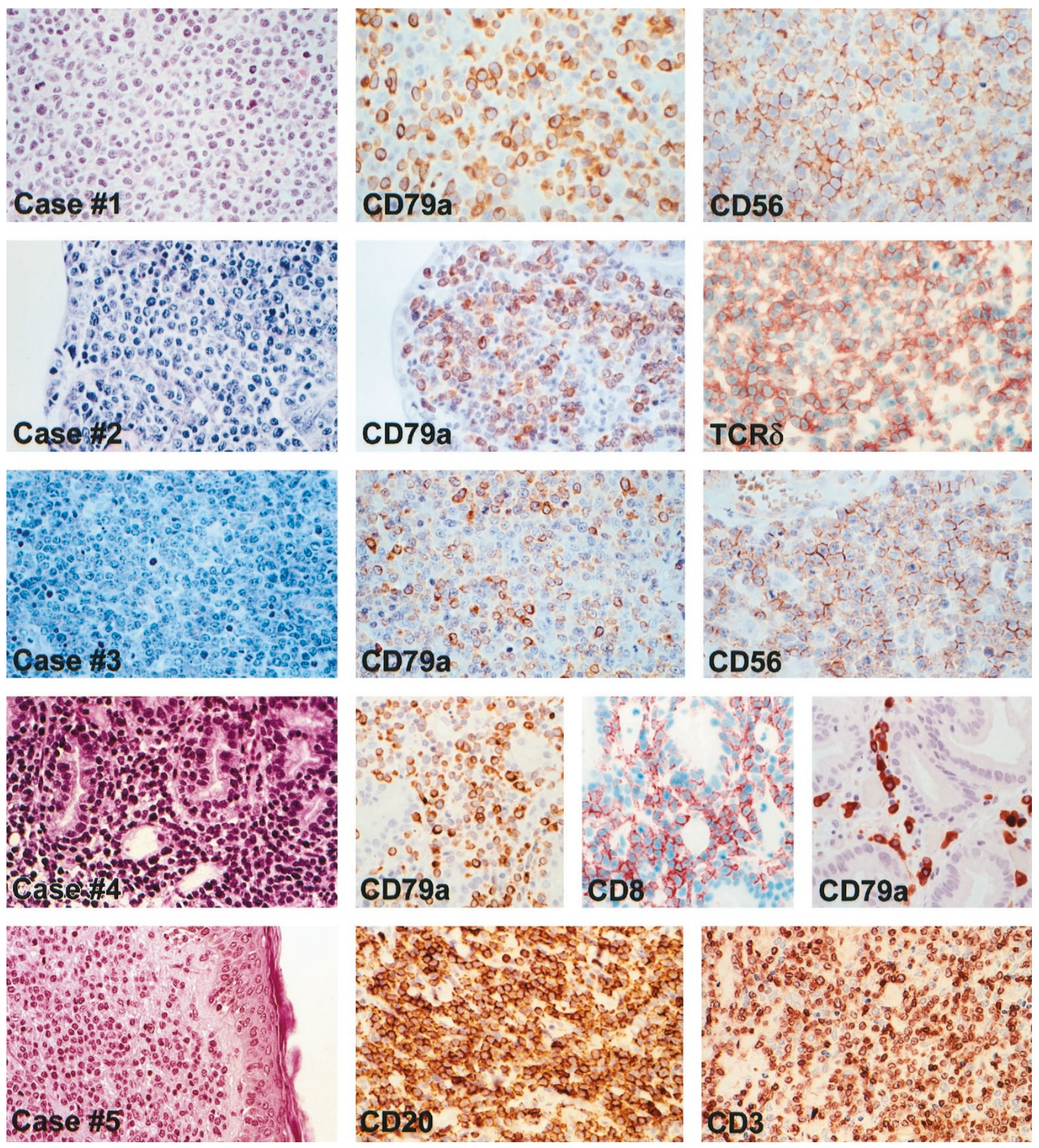

FIGURE 1. Histopathology (left row) and immunohistochemistry (images following to the right) of five B-cell marker (CD79a or L26) positive extranodal peripheral T-cell lymphomas (Cases 1 through 5). The CD79a-positive lymphomas are from nose (1), jejunum (2 and 3), and stomach (4). The majority of lymphoma cells show CD79a staining that is slightly weaker than on reactive plasma cells, as shown for Case 4 (left). The cutaneous lymphoma (Case 5) stains strongly for L26 (CD20). Hematoxylin and eosin staining in Cases 1, 4, and 5; Giemsa staining in Cases 2 and 3 . All images at same magnification.

jacent tissue. The comparative plasma cell labeling, which served as a positive internal control in all cases, is shown in Case 4 (Fig. 1). In two cases (1 and 4), two biopsies each from different sites were available: the tumor cells at the nasal site (Case 1) and in the gastric biopsy (Case 4) stained for CD79a, whereas the lymphomatous tissue at the second site was negative (Table 2). As mentioned above, all four CD79a reactive lymphomas were negative for CD20.
In Case 5 a plaque-like cutaneous infiltrate extending into the deep dermis stained strongly for CD20 but was negative for CD79a. Phenotyping on frozen sections entirely confirmed the results obtained in paraffin sections and, in addition, revealed lack of reactivity to the B-cell-associated antigen CD19 (data not shown). It is interesting that the tumor cells were strongly positive with the monoclonal antibody HECA-452, which detects the cutaneous lymphocyte antigen expressed on nor- 


\begin{tabular}{|c|c|c|c|c|c|c|c|}
\hline \multirow{2}{*}{ Antibody } & \multicolumn{2}{|c|}{ Case 1} & \multirow{2}{*}{$\begin{array}{c}\text { Case } 2 \\
\text { Jejunum }\end{array}$} & \multirow{2}{*}{$\frac{\text { Case } 3}{\text { Jejunum }}$} & \multicolumn{2}{|c|}{ Case 4} & \multirow{2}{*}{$\begin{array}{l}\text { Case } \\
5 \\
\text { Skin }\end{array}$} \\
\hline & Nose & Skin & & & Stomach & Ileum & \\
\hline CD79a & + & - & + & + & + & - & - \\
\hline L26 (CD20) & - & - & - & - & - & - & + \\
\hline$\beta \mathrm{F} 1$ & + & + & $\beta \mathrm{F} 1-/ \mathrm{TCR} \delta+^{b}$ & - & - & - & + \\
\hline CD3e/cyt. & + & + & + & + & + & + & + \\
\hline $\mathrm{CD} 2$ & - & - & - & + & + & + & - \\
\hline CD5 & + & + & - & - & - & - & + \\
\hline $\mathrm{CD} 7$ & + & + & + & ND & + & + & \pm \\
\hline $\mathrm{CD} 4$ & - & - & - & - & - & - & - \\
\hline CD8 & - & - & - & + & + & + & - \\
\hline CD56 & + & + & - & + & - & - & - \\
\hline TIA-1 & $\mathrm{i}+{ }^{c}$ & - & + & + & + & + & \pm \\
\hline GB-4 & $\mathrm{i}+$ & - & + & + & + & + & $\mathrm{i}+$ \\
\hline CD30 & - & - & - & - & + & + & - \\
\hline EMA & - & - & - & - & ND & + & - \\
\hline HECA-452 & - & - & - & ND & - & - & + \\
\hline MIB 1 & $70 \%$ & $70 \%$ & $80 \%$ & $90 \%$ & ND & $65 \%$ & $15 \%$ \\
\hline EBER-ISH & - & - & - & - & ND & - & - \\
\hline TCR $\gamma$-PCR & + & + & + & + & + & + & + \\
\hline IgH-PCR & - & - & - & - & - & - & - \\
\hline
\end{tabular}

ISH, in situ hybridization; TCR $\gamma$-PCR, T-cell receptor $\gamma$-chain gene-polymerase chain reaction; IgH-PCR, immunoglobulin heavy chain genepolymerase chain reaction.

${ }^{a}$ All cases negative for CD34, TdT, CD1a, CD57, and LMP1.

${ }^{b}$ TCR $\delta$ staining on frozen section.

${ }^{c} \mathrm{i}+$, individual tumor cells positive.

$\mathrm{mal} /$ reactive cutaneous $\mathrm{T}$ cells and on the majority of primary cutaneous T-cell lymphomas $(16,17)$.

Because CD79a and L26 (CD20) are regarded as excellent markers of neoplastic B-cell proliferations, comprehensive immunophenotypic and genotypic studies were undertaken to evaluate lineage derivation and clonality of the four lymphomas that were positive for CD79a and the lymphoma that was reactive to CD20. Lack of reactivity to CD20 (in the four CD79a-positive cases) and to CD79a and CD19 (in the CD20-positive case) and to antigens expressed in precursor $\mathrm{T}$ - and B-cell lymphomas (CD34, TdT, CD1a) but constant expression of CD3 and proteins associated with cytotoxic granules (TIA-1, GB-4) and variable reactivity to T-cell receptor-associated antibodies ( $\beta \mathrm{F} 1$ or TCR $\delta 1)$ and to T/NK-cell associated antibodies (CD2, CD7, CD56) provided strong immunophenotypic evidence of cytotoxic T- or NK/T-cell derivation. Finally, genotypic studies demonstrated monoclonal rearrangements of the T-cell receptor $\gamma$-chain genes (Fig. 2)

CD79a+ Cases (\#1-\#4)

M \#1a \#1b \#2 \#3 \#4a \#4b PC -Co

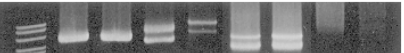

FIGURE 2. T-cell receptor $\gamma$-chain gene rearrangement of amplified genomic DNA extracted from paraffin sections of four CD79a+ (Cases 1 through 4) and one L26 (CD20) + (Case 5) extranodal peripheral T-cell lymphomas. One or two dominant bands indicating clonal mono- or biallelic rearrangements are present in all tumor specimens. Bone marrow (BM) and peripheral blood (PB) samples of Case 5 are negative. PC, polyclonal control; -Co, negative control (no DNA added). and lack of monoclonal immunoglobulin heavy chain gene rearrangement (not shown), indicating (in combination with the immunophenotypic findings) that all five cases were indeed cytotoxic peripheral T-cell lymphomas. Bone marrow and peripheral blood samples obtained from the CD20positive PTL (Case 5) during initial staging and peripheral blood samples at 3 and 6 months after diagnosis did not show evidence of lymphoma dissemination (Fig. 2, right panel).

EBER transcripts were undetectable in all five cases.

\section{DISCUSSION}

The monoclonal antibody CD79a (clone JCB117), which recognizes the mb-1 polypeptide of the B-cell antigen receptor complex, has been introduced as an excellent marker for B-cell neoplasms that are reactive in routinely processed tissue samples. Because all neoplasms of T-cell or nonlymphoid origin have been negative and the antibody reacted with B-cell neoplasms covering the full range of B-cell maturation, it was judged superior to other commercially available B-cell markers, such as those directed against CD20, CD38, CD45RA, CD74, and CDw75 (9). A subsequent report on a large series of lymphoblastic leukemia/ lymphoma cases, however, demonstrated coexpression of CD3 and CD79a in approximately $10 \%$ of precursor T-cell lymphoblastic leukemia/lymphoma neoplasms (18), and another study found a 
high frequency of CD79a expression (clone HM57) in acute promyelocytic leukemia (19).

To the best of our knowledge, no investigation has focused on the reactivity of CD79a in extranodal peripheral T-cell or NK/T-cell lymphomas. The present study was undertaken after the personal observation of a CD79-positive intestinal T-cell lymphoma (Case 3 in this series) and was stimulated additionally by the IX Meeting of the European Association for Hematopathology in Leiden (1998), at which CD79a reactivity had been noted in very few extranodal PTLs. By screening a large series of primary extranodal peripheral T-cell and NK/T-cell lymphomas, comprising the welldefined clinicopathologic entities of enteropathytype intestinal T-cell lymphoma and nasal NK/Tcell lymphoma, as well as several subtypes of cutaneous lymphomas, four CD79-positive lymphomas that all were CD20 negative were identified: three enteropathy-type intestinal T-cell lymphomas and one nasal NK/T-cell lymphoma. Two of the enteropathy-type intestinal T-cell lymphomas (Cases 2 and 3) microscopically simulated lowgrade B-cell lymphoma of MALT type. This observation has important clinical implications as enteropathy-type intestinal T-cell lymphoma is a very aggressive disease (13), whereas low-grade B-cell lymphoma of MALT type usually follows a prolonged indolent course (20). To minimize the risk of misdiagnosis, especially in small endoscopic or surgical biopsies, we suggest the use of both CD79a and CD20 in combination with a panel of antibodies that are reactive to $\mathrm{T}$ cells, such as $\beta \mathrm{F} 1$ and CD5, and to T cells and NK cells, such as CD3, CD2, CD56, and TIA-1.

The biology of CD79a reactivity in these non-Bcell lymphomas is not clear. Surface immunoglobulin (Ig) on B cells is noncovalently associated with the CD79 heterodimer comprising mb-1 (CD79a) and B29 (CD79b) transmembrane polypeptide chains, which both are required for the expression of surface Ig (21). Although discordant expression of Ig and CD79a (Ig-negative/CD79a-positive) occurs frequently in mediastinal large B-cell lymphomas and in a minority of follicular lymphomas (22), none of these B-cell receptor components is expressed in normal or neoplastic peripheral $\mathrm{T}$ cells (23). Thus, aberrant expression of CD79a seems to be very unlikely, whereas cross-reactivity with unknown epitope(s) represents a plausible explanation. The latter is underscored by the inconstant reactivity of CD79a observed in the two cases from which sequential biopsies were available (Cases 1 and 4): the initial biopsies each showed CD79a staining in the majority of the tumor cells, whereas the second biopsies clearly were negative (Table 2).

To the best of our knowledge, Case 5 of this series represents the first CD20-positive primary cutane- ous T-cell lymphoma. The monoclonal antibody L26 recognizes an intracellular epitope of CD20 and has been shown to be a valuable reagent for the diagnosis of B-cell lymphomas in routinely processed tissues $(3-8,24)$. A few cases of CD20positive (L26) nodal PTLs, however, have been reported $(5,10,11)$. The most recent case study suggested that the CD20-positive nodal PTL evolved from neoplastic transformation of a normal subset of CD20-positive peripheral blood T cells, which argues against aberrant CD20 expression by the neoplastic $\mathrm{T}$ cells $(11,25)$. In contrast, the CD20-positive cutaneous PTL presented herein is probably derived from skin-homing $\mathrm{T}$ cells because of the reactivity to cutaneous lymphocyte antigen that is preferentially expressed on normal and neoplastic cutaneous T cells $(16,17)$. Similar to the two enteropathy-type intestinal T-cell lymphomas discussed above, the CD20-positive cutaneous PTL could easily be mistaken for low-grade B-cell lymphoma. The clinical significance of correct lineage assignment and diagnosis is emphasized again by the more aggressive behavior of the PTL as compared with low-grade cutaneous B-cell lymphomas $(26,27)$.

In summary, this study revealed mutually exclusive reactivity of the widely used B-cell markers CD79a or L26 in a very small proportion of extranodal cytotoxic PTLs and a case of a nasal NK/T-cell lymphoma. As our series was biased toward certain entities and did not cover the full spectrum of predominantly extranodal malignant T-cell and NKcell neoplasms, it cannot be excluded that CD79a reactivity might also occur in other non-B-cell lymphomas, such as subcutaneous panniculitis-like T-cell lymphoma, hepatosplenic $\gamma / \delta$ T-cell lymphoma, and blastoid NK-cell lymphoma. To minimize the risk of misinterpretation of lymphoma cell lineage, especially in cases of extranodal lymphoproliferative disease, we suggest the use of both CD79a and L26 in combination with a panel of antibodies that are reactive to T cells, such as $\beta \mathrm{F} 1$ and CD5, and to T cells and NK cells, such as CD3, CD2, CD56, and TIA-1.

\section{REFERENCES}

1. Harris NL, Jaffe ES, Stein H, Banks PM, Chan JKC, Cleary ML, et al. A revised European-American classification of lymphoid neoplasms: a proposal from the International Lymphoma Study Group. Blood 1994;84:1361-92.

2. Frizzera G, Wu CD, Inghirami G. The usefulness of immunophenotypic and genotypic studies in the diagnosis and classification of hematopoietic and lymphoid neoplasms. Am J Clin Pathol 1999;111(Suppl 1):S13-39.

3. Cartun RW, Coles FB, Pastuszak WT. Utilization of monoclonal antibody L26 in the identification and confirmation of B-cell lymphomas. A sensitive and specific marker applicable to formalin- and B5-fixed, paraffin-embedded tissues. Am J Pathol 1987;129:415-21. 
4. Davey FR, Gatter KC, Ralfkiaer E, Pulford KA, Krissansen GW, Mason DY. Immunophenotyping of non-Hodgkin's lymphomas using a panel of antibodies on paraffin-embedded tissues. Am J Pathol 1987;129:54-63.

5. Norton AJ, Isaacson PG. Monoclonal antibody L26: an antibody that is reactive with normal and neoplastic B lymphocytes in routinely fixed and paraffin wax embedded tissues. J Clin Pathol 1987;40:1405-12.

6. Linder J, Ye Y, Armitage JO, Weisenburger DD. Monoclonal antibodies marking B-cell non-Hodgkin's lymphoma in paraffin-embedded tissue. Mod Pathol 1988;1:29-34.

7. Segal GH, Stoler MH, Fishleder AJ, Tubbs RR. Reliable and cost-effective paraffin section immunohistology of lymphoproliferative disorders. Am J Surg Pathol 1991;15:1034-41.

8. Chadburn A, Knowles DM. Paraffin-resistant antigens detectable by antibodies L26 and polyclonal CD3 predict the Bor T-cell lineage of 95\% of diffuse aggressive non-Hodgkin's lymphomas. Am J Clin Pathol 1994;102:284-91.

9. Mason DY, Cordell JL, Brown MH, Borst J, Jones M, Pulford $\mathrm{K}$, et al. CD79a: a novel marker for B-cell neoplasms in routinely processed tissue samples. Blood 1995;86:1453-9.

10. Hamilton-Dutoit SJ, Pallesen G. B cell associated monoclonal antibody L26 may occasionally label T cell lymphomas. APMIS 1989;97:1033-6.

11. Quintanilla-Martinez L, Preffer F, Rubin D, Ferry JA, Harris NL. CD20+ T-cell lymphoma. Neoplastic transformation of a normal T-cell subset. Am J Clin Pathol 1994;102:483-9.

12. Jaffe ES, Krenacs L, Kumar S, Kingma DW, Raffeld M. Extranodal peripheral T-cell and NK-cell neoplasms. Am J Clin Pathol 1999;111(Suppl 1):S46-55.

13. Chott A, Haedicke W, Mosberger I, Födinger M, Winkler K, Mannhalter C, et al. Most CD56+ intestinal lymphomas are CD8+CD5- T-cell lymphomas of monomorphic small to medium size histology. Am J Pathol 1998;153:1483-90.

14. Födinger M, Winkler K, Mannhalter C, Chott A. Combined polymerase chain reaction approach for clonality detection in lymphoid neoplasms. Diagn Mol Pathol 1999;8:80-91.

15. Frank SF, Svoboda-Newman SM, Hsi ED. Comparison of methods for extracting DNA from formalin-fixed paraffin sections for nonisotopic PCR. Diagn Mol Pathol 1996;5:220-4.

16. Picker LJ, Michie SA, Rott LS, Butcher EC. A unique phenotype of skin-associated lymphocytes in humans. Preferential expression of the HECA-452 epitope by benign and malignant T cells at cutaneous sites. Am J Pathol 1990;136:1053-
68.

17. Noorduyn LA, Beljaards RC, Pals ST, Van Heerde P, Radaszkiewicz T, Willemze R, et al. Differential expression of the HECA-452 antigen (cutaneous lymphocyte associated antigen, CLA) in cutaneous and non-cutaneous T-cell lymphomas. Histopathology 1992;21:59-64.

18. Pilozzi E, Pulford K, Jones M, Müller-Hermelink HK, Falini B, Ralfkiaer E, et al. Co-expression of CD79a (JCB117) and CD3 by lymphoblastic lymphoma. J Pathol 1998;186:140-3.

19. Arber DA, Jenkins KA, Slovak ML. CD79 $\alpha$ expression in acute myeloid leukemia. High frequency of expression in acute promyelocytic leukemia. Am J Pathol 1996;149:1105-10.

20. Thieblemont C, Bastion J, Berger F, Rieux C, Salles G, Dumontet $\mathrm{C}$, et al. Mucosa-associated lymphoid tissue gastrointestinal and nongastrointestinal lymphoma behavior: analysis of 108 patients. J Clin Oncol 1997;15:1624-30.

21. Van Noesel CJM, Van Lier RAW. Architecture of the B-cell antigen receptors. Blood 1993;82:363-73.

22. Kanavaros P, Gaulard P, Charlotte F, Martin N, Ducos C, Lebezu M, et al. Discordant expression of immunoglobulin and its associated molecule mb-1/CD79a is frequently found in mediastinal large B cell lymphomas. Am J Pathol 1995; 146:735-41.

23. Mason DY, Cordell JL, Tse AGD, van Dongen JJ, van Noesel $\mathrm{CJ}$, Micklem K, et al. The IgM-associated protein mb-1 as a marker of normal and neoplastic B cells. J Immunol 1991; 147:2474-82.

24. Mason DY, Comans-Bitter WM, Cordell JL, Verhoeven MA, van Dongen JJ. Antibody L26 recognizes an intracellular epitope on the B-cell-associated CD20 antigen. Am J Pathol 1990;136:1215-22.

25. Hultin LE, Hausner MA, Hultin PM, Giorgi JV. CD20 (pan B-cell) antigen is expressed at a low level on a subpopulation of human T lymphocytes. Cytometry 1993;14:196-204.

26. Cerroni L, Signoretti S, Hšfler G, Annessi G, Pütz B, Lackinger $\mathrm{E}$, et al. Primary cutaneous marginal zone B-cell lymphoma: a recently described entity of low-grade malignant cutaneous B-cell lymphoma. Am J Surg Pathol 1997;21:1307-15.

27. Willemze R, Kerl H, Sterry W, Berti E, Cerroni L, Chimenti S, et al. EORTC classification for primary cutaneous lymphomas: a proposal from the cutaneous lymphoma study group of the European organization for research and treatment of cancer. Blood 1997;90:354-71. 